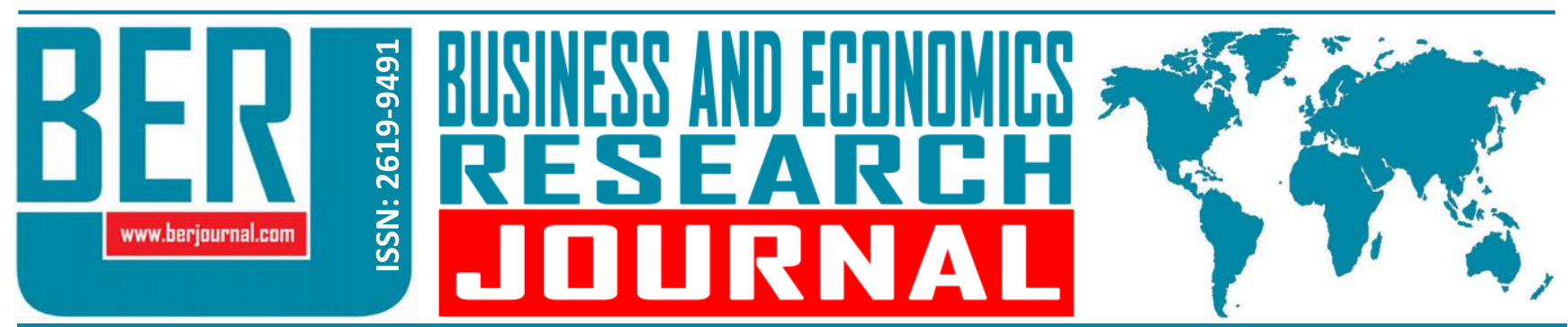

Business and Economics Research Journal Vol. 10, No. 1, 2019, pp. 131-148 doi: 10.20409/berj.2019.159

\title{
Relationships among Leader Effectiveness, Learning Orientation, Effective Communication, Team Creativity and Service Innovation in the Service Sector
} Zafer Adiguzel $^{\mathrm{a}}$

\begin{abstract}
If the companies in the service sector do not express themselves correctly and do not provide the required service, they fall behind in the competition race and have to leave the sector. Thus, the effect of leadership within senior managers on employees is reflected in organisation performance, which gain more importance every day. The purpose of this study is to analyse the relationships between the variables of leader effectiveness, learning orientation and effective communication, and team creativity and service innovation. As a result of our analyses, it was determined that leadership effectiveness and learning orientation have a positive impact on effective communication, team creativity, and service innovation. This indicates that if an organisation has effective leadership and learning orientation, it positively contributes to effective communication, team creativity, and service innovation in the service sector. 348 questionnaires collected from white-collar employees were used for evaluation; factor and reliability analysis were conducted on the Likert scale questions; correlation analysis was carried out to examine the relationships between variables; regression analysis was performed to test the hypotheses.
\end{abstract}

\author{
Keywords: Leadership \\ Effectiveness, Learning \\ Orientation, Effective \\ Communication, Team \\ Creativity, Service Innovation
}

JEL: L20, L84, M10, D83

$\begin{array}{ll}\text { Received } & : 03 \text { September } 2018 \\ \text { Revised } & : \text { 26 October } 2018 \\ \text { Accepted } & : \text { :04 December } 2018 \\ & \\ \text { Type } & : \text { Research }\end{array}$

\section{Introduction}

Leaders should be able to improve their relationships with the employees, and at the same time, they should generate team creativity in order to improve organisation performance. Although, individual creativity is important for team creativity, it is not entirely composed by individual creativity, rather, it emerges synergistically when employees interact with each other in several ways. Taggar (2002) states that team creativity is not the basic sum of individual creativity and emphasizes the importance of the process of team creativity in the organisation, especially in a competitive environment (for example, raising the targets for group members, providing feedback, organizing employees' contributions, coordinating employees to be effective in team creativity and motivating employees to reveal different ideas, needs, views, etc.). Another important issue for the organisation is learning orientation, which is defined as "a company's ability to create knowledge, to acquire knowledge, to transfer knowledge and to change the behaviour of employees to reflect new knowledge" (Garvin, 1993).

Researchers working on the concept of learning orientation suggest that this new concept has the potential to change the behaviour of an organization (Sinkula, 1994). For example, Huber (1991) describes learning orientation as a change of behaviour in the process of 'an organization or a department to acquire 
information accepted to be potentially useful for the organization', as well as during the process of understanding 'if a company has learned through information processing'. Learning orientation helps to reduce the effects of possible failures in the organization with the support of leader effectiveness (Button et al., 1996). Santos-Vijande, López-Sánchez and González-Mieres (2012) explain that learning orientation creates an organizational culture that promotes the development of new knowledge and insight. This situation promotes the desire of the employees for the institutionalization of the organisation and develops the ability of innovation.

A number of studies that examine new service development processes are slowly emerging (Jaw et al., 2010). As a matter of fact, there are various studies emphasizing the increasing importance of service innovation (Ordanini \& Parasuraman, 2011). For example, Oke (2007) determined that different management practices, including human resource applications, result in radical new that create service innovations that can differentiate a company, bring competitive advantages in the market, and require the use of strategic resources and assets. Innovations of the companies in the service sector are believed to bring advantages over competitors.

Clearly, the main purpose of an interaction in the business world is to share ideas and emotions in order to gain successful business opportunities. Thus, the ability to communicate is an important process. Ulijn and Strother (1995) argue that managers have an important role in developing successful communication conditions among employees within the organization, all of which depends on their communication skills. Especially in the service sector, organizations are in constant communication with consumers/customers and therefore they should pay more attention to communication quality. Indeed, the ability to communicate effectively is a prerequisite for successful management, especially for those at the management level and coming from different cultures (Limaye \& Victor, 1991). One of the most important conditions for leader effectiveness is to communicate properly, which will also ensure that the activities within the organization are more orderly coordinated.

\section{Leadership Effectiveness}

Effectiveness with regard to leadership refers to the ability of a leader to direct an organization towards the specified objectives in order to reach organisational goals (Green, 2010). Studies indicate that leadership effectiveness defines the ability of a leader to use personal influence, skills, and abilities to achieve anticipated goals or objectives (Cooper et al., 2012). Although, it has been accepted that leadership effectiveness is needed for organizational performance, there has been debate about common definitions of leader effectiveness between academics and researchers in the past (Arnold et al., 1998). Stogdill (1974), Bass $(1981,1990)$, catalogued and interpreted 5000 studies and stated that there are significant differences in the definitions. Burns emphasised these differences, (1978) and stated that leadership effectiveness is 'one of the most observed and least understood issue in the world'. For example, Sutcliffe (1998) defines leadership effectiveness as a process by which one person affects the behaviour of other people in order to achieve specified goals. Such a leader must earn the attentiveness and commitment of followers in order to achieve the stated goals. However, for most researchers, leadership effectiveness refers to the ability to direct appropriate skills, abilities, beliefs, and behaviours to achieve a desired goal (Green, 2010). To be effective, a leader's influence should leave a positive impression not only on direct followers but also on the whole organization.

Effective leaders should gain the admiration of the employees in order to earn their loyalty and commitment. The commitment of the employees is an important determinant of the effectiveness of a leader and ensures that targeted objectives can be achieved (Yukl, 2010). The effectiveness of a leader is determined by the understanding and inclusion of the employees in the organisation. However, this can only be achieved if leaders and subordinates both establish strong mutual trust and respect, and work as an organisation (Epitropaki \& Martin, 2005). Fleenor et al. (2010)'s hypothesis points out that 'leaders who are in accord with employees are more effective than tuneless leaders', but they reached a consensus that this relationship is a very complex one. Effective leaders are defined as leaders who can correctly identify their strengths and weaknesses and set self-development goals (Yammarino \& Atwater, 1997). It is suggested that the leaders 
who act positively are more effective than those who act in a negative direction (Tekleab et al., 2008). In general, previous studies revealed that there is a positive relationship between a favorable atmosphere in an organisation and leader effectiveness (Ostroff et al., 2004). Therefore, in this study, we examined the effects of leader effectiveness on learning orientation, team creativity, effective communication and service innovation, and the relationship between them.

\section{Learning Orientation}

Learning orientation is defined as the 'formation of a set of organizational cultures that influences the tendencies for creating and using information for the organisation (Sinkula et al., 1997). This definition shows that a learning orientation requires more than some short-term organizational training and development periods. It reflects the idea that the organizations are willing to "step back, observe their situation, get in line with their objectives, take time, and have the courage to change when necessary" (Gill, 2009). Learning orientation refers to the organization-wide effectiveness of creating and using knowledge to increase competitive advantage. This includes acquiring and sharing information about customer needs, market changes and competitor actions, as well as the development of new technologies to create superior new products / services (Calantone et al., 2002). Slater and Narver (1995) suggest that learning encourages behavioural changes for better performance. Researchers argue that organizational learning causes better outcomes such as new product success, customer retention, growth and/or profitability.

Organizational learning is associated with the development of new knowledge that is very important for the innovation and performance of a company (Hurley \& Hult, 1998). A learning-oriented organisation is likely to have the latest technology that leads to greater innovation capability in both products and processes (Mone et al., 1998). Mullen and Lyles (1993) indicate that a company's continuous orientation towards organizational learning can enhance the effectiveness and productivity of its innovative activities. Learning orientation improves the positive relationship between task conflicts and creativity. The tendency to develop new knowledge, stimulated by learning orientation, increases the versatility of the employees and encourages them to turn converse views into creative results (Brett \& VandeWalle, 1999). A strong learning orientation facilitates persistence, thereby promoting the internal motivation to turn conflict situations into creative results (Brett \& VandeWalle, 1999). According to Senge (1990), learning orientation is related to the ability of an organisation to expand its capacity over time. In general, learning organizations have a capacity to constantly improve themselves as they develop new patterns of thinking and their employees learn to see internal issues as a 'whole' in the organisation. For example, contrary to the private sector, in the public sector there are multiple factors, government regulations, non-participatory policy making, rigid organizational structures, and the culture of doing things as explained rather than learning that cause restrictions on the employees and make them ineffective (Denton, 1998). For this reason, in this study, we examine the effects of leader effectiveness on learning orientation and the relationship between them. In the aforementioned context the below hypothesis is developed;

\section{H1: Leader effectiveness has a positive effect on learning orientation.}

\section{Team Creativity}

Leaders can influence employees at individual and team levels. According to the theory of creativity, individual creativity is regarded as a building stone for team creativity (Drazin et al., 1999). The effectiveness of a leader in a team encourages a creative culture that rewards, supports, and anticipates creativity. In fact, an effective leader considers individual characteristics and differences and learns about the creativity styles of the members, coordinating the different styles to contribute to team creativity (Basadur, 2004). Leader effectiveness generates a supportive atmosphere for creativity. Employees in a creatively supportive environment will develop new ways of working and assist the work of others in order to generate creativity (West, 1990). Team creativity evolves from an individual creativity concept. At first, academicians generally decided that individual creativity did not differ from the understanding of basic creativity (Amabile, 1988). However, with the development of teamwork and increasingly widespread application of it in daily work, 
researchers have slowly begun to explore team creativity as a product of complex interpersonal interactions within a system, not as an individual feature (Leenders et al., 2003). For example, Pirola-Merlo and Mann (2004) describe team creativity as 'the sum of creative activities, in terms of individuals and in time. Taggar (2002) suggests that team creativity is the 'combination of interactive functions of individual creativity and the sum of processes related to team creativity".

Team creativity is fed by a degree of individual creativity. For this reason, it is very important that team leaders encourage each team member to show their creativity in order to improve team creativity. However, in many cases, depending on limited resources and time, leaders cannot develop high quality relationships with every team member. The extent of how these limited resources are allocated among the team members determines to some degree the success of the team. Apart from creative members, extroverts who are, conscious and well-liked group members tend to exhibit more harmonious behaviours in groups: eg. team creativity processes such as encouraging discussion, inspiring group members, creating focused team, and collaborating with other team members (Taggar, 2002). For this reason, if time and resources are limited, leaders may assign these employees to more challenging or more critical business tasks that may give them more confidence, courage, high expectations, and strong social-emotional support. As for other members (for example, subordinates with low ability or low performance), leaders can assign them to more heavy-duty tasks and provide them with lower-level support (Maslyn \& Uhl-Bien, 2001). The studies explain that the positive effects of team creativity can help to increase employee's individual creative activities, behaviours and task performances (Seong \& Choi, 2014). For this reason, we examine the effects of leadership effectiveness and learning orientation on team creativity and their relationship in this study. In the aforementioned context the below hypothesizes is developed;

H2: Leader effectiveness has a positive effect on team creativity.

H3: Learning orientation has a positive effect on team creativity.

H8: Learning orientation has an intervening variable effect on the relationship between leader effectiveness and team creativity.

\section{Service Innovation}

Organizations are aiming to provide service innovation by constantly making operational improvements, focusing on technology-driven thinking, investing in employee performance, supporting customer experience, and trying to provide new service concepts, or new business models for delivering service (Enz, 2012). The creation of new services by the companies together with their customers can help companies to be innovative (Hjalager \& Topic, 2011) because the feedback and suggestions of customers can ensure better service innovation for the company. According to theoretical studies, service innovation is seen as a linear and formal process (Essén, 2009). This approach emphasizes the importance of creating a good perception of service innovation as a regular set of activities that are controlled by management and supported by the organisation (Chae, 2012). Based on Essén's (2009) theory, Chae (2012) developed another service innovation model by adding unpredictable service innovation characteristics. According to this view, a new service can be created based on the interaction between economic actors and various sources such as service providers, customers (eg. system integration, administrative support, equipment, technology) (Chae, 2012). This view suggests that service innovation is created by service providers and their customers because of the unpredictable nature of interaction and structuring (Kristensson et al., 2008). For this reason, according to this view, service innovation is an evolutionary process that dynamically reassembles resources to meet customer needs. In a competitive environment, urgent planning can be more valuable than fixed planning for service innovation (Chae, 2012). Gadrey et al. (1995) explains that service innovation is generated by the innovation processes for existing service products. Den Hertog (2000) describes service innovation as a combination of customer feedback, service delivery systems, and possible technological solution.

Activities in the service sector require employees to develop creative thinking in order to generate inventive processes in organizations (Shah et al., 2010). Recent innovative behavioural models attempt to 
examine and understand employees' innovative behaviours (Hu et al., 2009). Such studies reveal a number of psychological factors, such as information sharing and team culture, which can interpret innovative behaviours of the employees. However, little is known about these key factors, which generally affect employee outcomes: leadership style, job characteristics, and employee motivation in an organization. Although the importance of innovative behaviours in the organization of the service sector receive increasing recognition (Mittal \& Dhar, 2015), the studies that examines the behaviours of the employees in service innovation are limited (Kim \& Lee, 2013). For this reason, in this study, we examine the effects of leader effectiveness and learning orientation on service innovation, and the relationship between them. In the aforementioned context the below hypothesizes is developed;

H4: Leader effectiveness has a positive effect on service innovation.

H5: Learning orientation has a positive effect on service innovation

H9: Learning orientation has an intervening variable effect on the relationship between leader effectiveness and service innovation.

\section{Effective Communication}

Communication is formal and informal information exchange between individuals at organisational or personal levels (Olkkonen et al., 2000). In the literature, researchers discovered the importance of communication as an effective approach to eliminate mutual suspicion, especially when performed timely, accurately, and properly (Yousafzai et al., 2005). Relationships are an important part of structuring, evaluating, and understanding messages in personal environments. Thus, relations are formed by interpersonal communication processes (Olkkonen et al., 2000). In some of the studies, they emphasize that effective communication has an important impact on the perception of relationship quality (Yen et al., 2011) because effective communication can help to resolve disputes. It removes misunderstandings, creating an opportunity for healthy and constructive discussion (Massey \& Dawes, 2007). Effective communication includes sharing meaningful and timely information between parties, both formal and informal (Sharma \& Patterson, 1999). Furthermore, Sanzo et al. (2003) argue that effective two-way communication between individuals implies regular, multi-level, and quality exchange of information. The characteristics of effective communication are specified as bidirectional (between individuals), formal or informal, meaningful and regular. For this reason, the effective communication of an employee depends on the level of the requests and feedbacks, routine communication flows, and the provision of useful information.

Effective communication is associated with a higher perceived relationship effectiveness and lowlevels of conflict because it reduces uncertainty, facilitates dialogue, and provides an opportunity for constructive discussion (Massey \& Dawes, 2007). In addition, effective communication provides opportunities for individuals to know each other, as well as generating awareness of what individuals expect from each other and what is needed to ensure healthy communication (Yen et al., 2011). However, Jehn and Bendersky (2003) argue that despite the time and effort of individuals for effective communication, if there is a high level of task conflict, the efficiency of reaching consensus may decrease (Jehn \& Bendersky, 2003). Furthermore, Jehn and Mannix (2001) state that if there is no effective communication, the conflicts between individuals often reduce the possibility of reaching a consensus and resulting productivity. If there is a high level of effective communication in the organisation, there will be low-levels of conflicts of interest between the employees, in this case, the expectations of the employees will be met and this will lead to high levels of job satisfaction. On the other hand, if there is high-level task conflict, this situation fails to satisfy the expectations of the employees and this will cause low-levels of employee satisfaction. For this reason, in this study, we examine the effects of leader effectiveness and learning orientation on effective communication and their relationships. In the aforementioned context the below hypothesizes is developed;

H6: Leader effectiveness has a positive effect on effective communication.

H7: Learning orientation has a positive effect on effective communication. 
H10: Learning orientation has an intervening variable effect on the relationship between leader effectiveness and effective communication.

\section{Research Framework}

Based on the literature review, research model was composed of independent variables of leader effectiveness and learning orientation and dependent variables of effective communication, team creativity, and service innovation. The sample of the study is composed of white collars in the service sector, which is a highly dynamic sector. The variables mentioned in the research model are preferred because they are one of the sectors in which they will be best researched. The aim of the study is to measure the impact of learning and leadership on the creativity, communication, and innovativeness of the white-collar workers in the targeted service sector. Among the employees in the service sector, learning orientation, effective communication, team creativity and innovation in service are important because the sector is in a dynamic structure. Study adapted a quantitative approach because the data was analysed to determine the relationship between statistical concepts. In a quantitative research, researchers use independent variable(s) to determine their effect on the dependent variable (Thomas et al., 2015).

Figure 1. Research Model

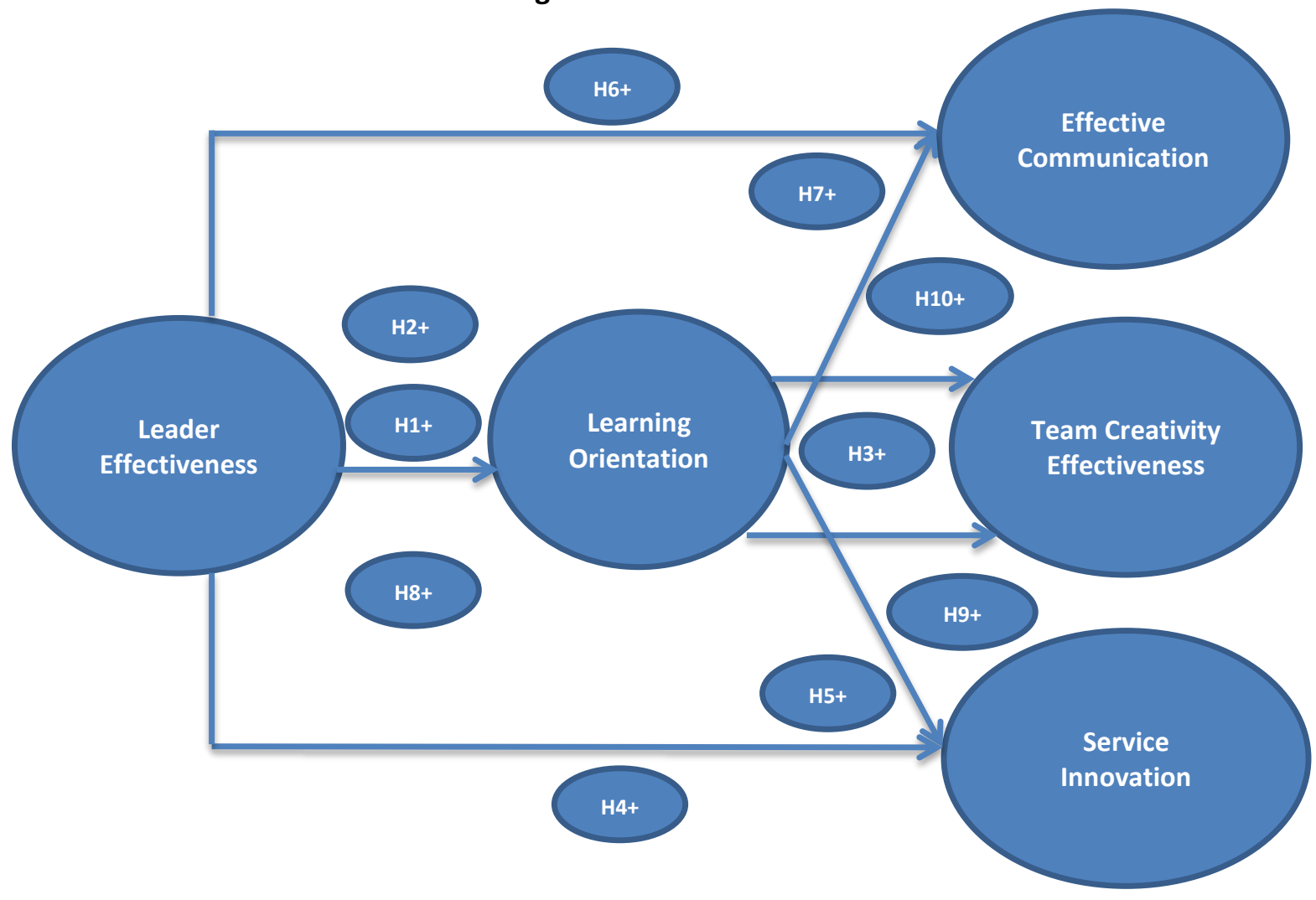

\section{Research Methodology}

\subsection{Method}

A survey was conducted with 348 employees in line with the purpose of the study. Data was evaluated using SPSS 23.00 Statistical Package Program and the demographic information was subject to 'descriptive' analysis. Likert scale questions were subjected to factor and reliability analyses. Correlation analysis was carried out to examine the relationships between variables; Regression analysis was performed to test the hypotheses. Leader effectiveness scale ( 6 questions) was composed by the questions developed 
by Yefei, Lee and Cheng in 2016. Learning orientation scale was measured with 8 questions developed by Hatane in 2015. Effective communication (5 questions) were adapted from the scale used by Sharma and Patterson in 1999. Team creativity scale was measured with 4 questions developed by Tierney and Farmer in 2002. Service innovation scale was developed by Swink (2003).

\subsection{Findings}

The sample of our Likert scale survey consisted of 348 white-collar employees working in different departments of private and public organisations. Our survey participation was 158 female employees and 190 male white-collar employees. Ages of the participants of the survey were distributed as; $13 \%$ between the ages of 18-25 (45 participants), 29\% between 26-30 (102 participants), 22\% between 31-35 (79 participants), $21 \%$ between $36-40$ (73 participants), $8 \%$ between $41-45$ (27 participants) and $6 \%$ of the participants were 46 years and over (22 participants). $40 \%$ of the employees were working in the public sector (137 employees) and 60\% are in the private sector (211 employees). The employees were working for their organisations as; $10 \%$ for less than 1 year (34 employees), 25\% for 1-3 years (86 employees), 33\% for 4-7 years ( 117 employees), $18 \%$ for $8-10$ years ( 62 employees), $14 \%$ for 10 years and over ( 49 employees). $1.5 \%$ of the participant had a primary school education ( 5 participants), $7 \%$ had high school or similar education (23 participants), 11\% had vocational school / associate degrees (37 participants), $67 \%$ had university degrees (233 Participants), $14.3 \%$ of them had graduate degrees (50 Participants).

In study, the variables were prepared according to the 5 point Likert scale and were measured by a questionnaire of 26 questions. Variables of leadership effectiveness, learning orientation, effective communication, team creativity and service innovation were subjected to factor analysis. As the result, 1 question did not show factor distribution, loaded into different factors and decreased the reliability and therefore it was subtracted from the scale. The remaining 25 questions were distributed into 5 factors. The variables that were subjected to factor analysis with their factor loads are shown in the following table:

Table 1. KMO and Bartlett's Test

\begin{tabular}{|l|l|r|}
\hline \multicolumn{3}{|c|}{ KMO and Bartlett's Test } \\
\hline Kaiser-Meyer-Olkin Measure of Sampling Adequacy & 0.930 \\
\hline \multirow{2}{*}{ Bartlett's Test of Sphericity } & Approx. Chi-Square & 5763.713 \\
\cline { 2 - 3 } & df & 300 \\
\cline { 2 - 3 } & Sig. & 0.000 \\
\hline
\end{tabular}

Factor analysis was performed to examine the validity of the structure of the scale. Büyüköztürk (2005) defines factor analysis as a multivariate statistical method aiming to discover a small number of unrelated but conceptually significant new variables (factors, dimensions) by bringing related variables together. 
Relationships among Leader Effectiveness, Learning Orientation, Effective Communication, Team Creativity and Service Innovation in the Service Sector

Table 2. Rotated Component Matrix ${ }^{\mathrm{a}}$

\begin{tabular}{|c|c|c|c|c|c|}
\hline \multicolumn{6}{|l|}{ Rotated Component Matrix ${ }^{a}$} \\
\hline & \multicolumn{5}{|c|}{ Component } \\
\hline & 1 & 2 & 3 & 4 & 5 \\
\hline LE4. I like working with our manager. & 0.841 & & & & \\
\hline LE2. Our manager has strong influence on employees. & 0.831 & & & & \\
\hline LE3. Our manager constantly motivates employees. & 0.817 & & & & \\
\hline $\begin{array}{l}\text { LE6. I believe our manager will be very successful in his/her future } \\
\text { assignments }\end{array}$ & 0.815 & & & & \\
\hline LE5. Our manager is very successful. & 0.814 & & & & \\
\hline LE1. Our manager is a good leader. & 0.760 & & & & \\
\hline $\begin{array}{l}\text { LO5. In the organisation I work for, the employees are awarded if they take } \\
\text { initiatives. }\end{array}$ & & 0.763 & & & \\
\hline $\begin{array}{l}\text { LO7.The organisation I work for cooperates with non-governmental } \\
\text { organizations to maintain good relations with the stakeholders. }\end{array}$ & & 0.677 & & & \\
\hline $\begin{array}{l}\text { LO4. The organisation I work for provides all employees with learning (self- } \\
\text { improvement) opportunities. }\end{array}$ & & 0.675 & & & \\
\hline $\begin{array}{l}\text { LO2. In the organisation I work for, the employees are trying to build trust } \\
\text { with each other. }\end{array}$ & & 0.656 & & & \\
\hline $\begin{array}{l}\text { LO8. In the organisation I work for, the managers always have willingness to } \\
\text { learn (self-improvement). }\end{array}$ & & 0.619 & & & \\
\hline $\begin{array}{l}\text { LO3. In the organisation I work for, each employee is prepared to accept an } \\
\text { agreement on the outcome of the discussion group despite the different } \\
\text { opinions. }\end{array}$ & & 0.570 & & & \\
\hline $\begin{array}{l}\text { LO1. In the organisation I work for, the employees are rewarded for their } \\
\text { efforts to learn (self-improvement efforts). }\end{array}$ & & 0.569 & & & \\
\hline LO6. The organisation I work for solves employees' problems. & & 0.550 & & & \\
\hline $\begin{array}{l}\text { TCE2.In the organisation I work for, I think I am good at generating new } \\
\text { ideas. }\end{array}$ & & & 0.767 & & \\
\hline $\begin{array}{l}\text { TCE1. In the organisation I work for, I am confident about my ability to solve } \\
\text { problems creatively. }\end{array}$ & & & 0.728 & & \\
\hline $\begin{array}{l}\text { TCE4. In the organisation I work for, I am good at finding creative ways to } \\
\text { solve the problems. }\end{array}$ & & & 0.699 & & \\
\hline $\begin{array}{l}\text { TCE3. In the organisation I work for, I think that I am a master in developing } \\
\text { the ideas of others. }\end{array}$ & & & 0.668 & & \\
\hline $\begin{array}{l}\text { EC4. In the organisation I work for, my colleagues will explain their mistakes } \\
\text { without hesitation. }\end{array}$ & & & & 0.763 & \\
\hline $\begin{array}{l}\text { EC3. In the organisation I work for, an employee in one department does not } \\
\text { hesitate to give required information to another department. }\end{array}$ & & & & 0.701 & \\
\hline $\begin{array}{l}\text { EC5. In the organisation I work for, my colleagues always share their } \\
\text { successful experiences. }\end{array}$ & & & & 0.683 & \\
\hline $\begin{array}{l}\text { EC2. In the organisation I work for, my colleagues explain some problems } \\
\text { and suggestions in a meaningful way. }\end{array}$ & & & & 0.581 & \\
\hline $\begin{array}{l}\text { SI3. In the organisation I work for, we take the services of other companies } \\
\text { as an example to develop our new services. }\end{array}$ & & & & & 0.748 \\
\hline SI2. In the organisation I work for, we develop our new services. & & & & & 0.665 \\
\hline $\begin{array}{l}\text { SI4. In the organisation I work for, our new services are developed according } \\
\text { to the customer requirements. }\end{array}$ & & & & & 0.659 \\
\hline Extraction Method: Principal Component Analysis. Rotation Method: Varima & & & rmali & ion. ${ }^{a}$ & \\
\hline & & & & & \\
\hline
\end{tabular}

LE: Leader Effectiveness, LO: Learning Orientation, TCE: Team Creativity Effectiveness, EC: Effective

Communication, SI: Service Innovation

Confirmatory Factor Analysis; It is used to identify multivariate statistical analyzes, which contain the hidden structures represented by a large number of observed or measured variables (Aytaç et al., 2010:16; Özdamar, 2013:236). 
Figure 2. Model's AMOS Diagram

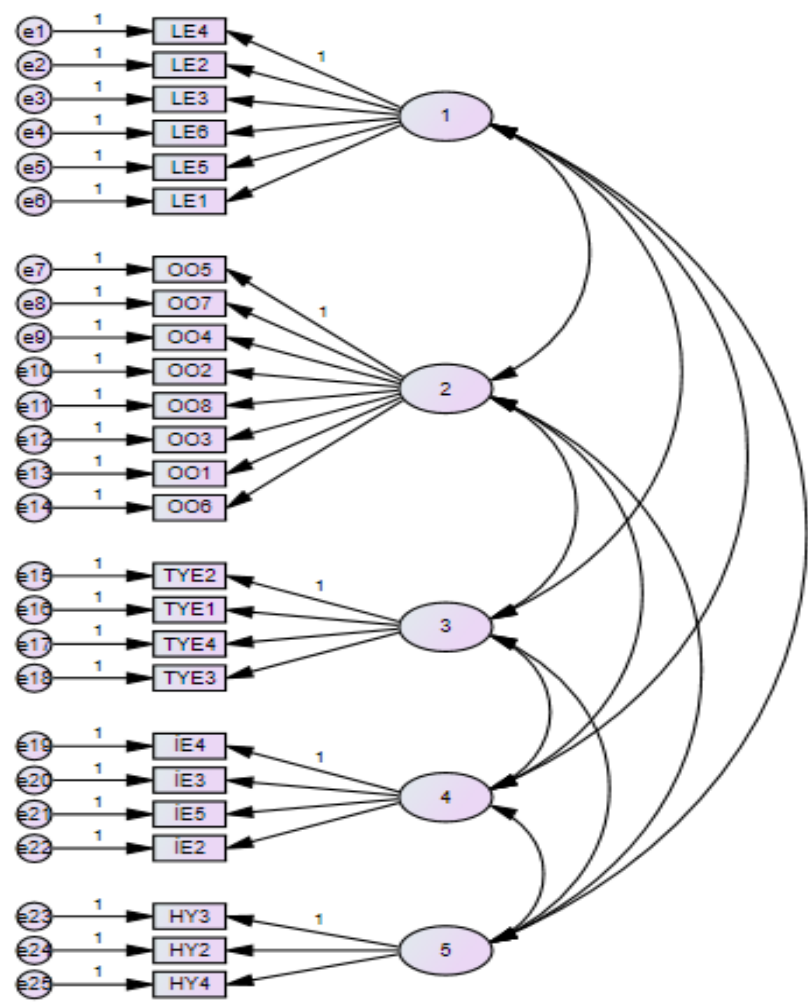

LE: Leader Effectiveness, OO: Learning Orientation, TYE: Team Creativity Effectiveness, IE: Effective Communication, HY: Service Innovation

Model Fit: Generally considered values for model fit; GFI, CFI, NFI, IFI and RMSEA (Schumacker, 2006 : 120; Illhan \& Çetin, 2014: 30-31). The reported values may vary according to the values the researcher wants to draw attention to. The compliance values obtained for the model generated as a result of the confirmatory factor analysis are given in Table 3 below.

Table 3. Confirmatory Factor Analysis

\begin{tabular}{|l|c|}
\hline Compliance Criteria & Values \\
\hline$\chi 2$ & 897.804 \\
\hline $\mathrm{Sd}$ & 265 \\
\hline$\chi 2 / s d$ & 3.388 \\
\hline GFI (Goodness of Fit Index) & 0.944 \\
\hline IFI (Incremental Fit Index) & 0.931 \\
\hline NFI (normed fit index) & 0.948 \\
\hline CFI (Comparative Fit Index) & 0.930 \\
\hline RMSEA (Root Mean Square Error of Approximation) & 0.062 \\
\hline
\end{tabular}

As seen in Table 3; $\mathrm{X}^{2} / \mathrm{df}=3.388<5,0.85<\mathrm{GFI}=0.944,0.90<\mathrm{IFI}=0.931,0.90<\mathrm{NFI}=0948,0.90<\mathrm{CFI}$ $=0.930$, RMSEA $=0.062<0.08$, compliance values According to the model shows compliance. Therefore, validity of the 5-factor structure revealed by explanatory factor analysis was confirmed by confirmatory factor analysis. 

Innovation in the Service Sector

Reliability analysis is defined as the internal consistency of the measurement which is about the average relation between the questions. In the literature, the Cronbach's alpha coefficient of 0.50 and above is accepted as sufficient by Nunnally (1978) (Nunnally, 1978; Hair et al., 2000; Büyüköztürk, 2007).

Table 4. Reliability Analysis

\begin{tabular}{|l|c|c|}
\hline VARIABLES & $\begin{array}{c}\text { Number of } \\
\text { Questions }\end{array}$ & $\begin{array}{c}\text { Cronbach Alfa } \\
(\boldsymbol{\alpha}) \text { Values }\end{array}$ \\
\hline Leader Effectiveness & 6 & 0.928 \\
\hline Learning Orientation & 8 & 0.898 \\
\hline Effective Communication & 4 & 0.851 \\
\hline Team Creativity Effectiveness & 4 & 0.827 \\
\hline Service Innovation & 3 & 0.734 \\
\hline
\end{tabular}

When the literature is examined, it is seen that reliability is checked before the validity in scale development studies because, if a scale is not reliable, it will not be valid. Therefore, there is no need to conduct a validity test for a scale that does not fulfil reliability standards (Çelik \& Bindak, 2005).

Table 5. Descriptive Statistics

\begin{tabular}{|l|c|c|c|}
\hline \multicolumn{4}{|c|}{ Descriptive Statistics } \\
\hline & Mean & Std. Deviation & $\mathrm{N}$ \\
\hline Leader Effectiveness & 3.7519 & 0.96774 & 352 \\
\hline Learning Orientation & 3.8726 & 0.87639 & 352 \\
\hline Team Creativity Effectiveness & 4.1108 & 0.74951 & 352 \\
\hline Effective Communication & 3.9858 & 0.88681 & 352 \\
\hline Service Innovation & 3.9872 & 0.81509 & 352 \\
\hline
\end{tabular}

Statistics is a science that deals with the collection, classification, presentation and interpretation of numerical data (Johnson, 1980). It is a method that aims to make the collected data meaningful using scientific methods (Linquist, 1989). Descriptive statistics include methods and techniques for collecting, describing, and presenting numerical data.

Table 6. Correlations

\begin{tabular}{|c|c|c|c|c|c|}
\hline \multicolumn{6}{|c|}{ Correlations } \\
\hline & $\begin{array}{c}\text { Leader } \\
\text { Effectiveness }\end{array}$ & $\begin{array}{l}\text { Learning } \\
\text { Orientation }\end{array}$ & $\begin{array}{c}\text { Team } \\
\text { Creativity } \\
\text { Effectiveness }\end{array}$ & $\begin{array}{c}\text { Effective } \\
\text { Communication }\end{array}$ & $\begin{array}{c}\text { Service } \\
\text { Innovation }\end{array}$ \\
\hline Leader Effectiveness & 1 & & & & \\
\hline Learning Orientation & $0.554^{* *}$ & 1 & & & \\
\hline Team Creativity Effectiveness & $0.348^{* *}$ & $0.636^{* *}$ & 1 & & \\
\hline Effective Communication & $0.429^{* *}$ & $0.729^{* *}$ & $0.587^{* *}$ & 1 & \\
\hline Service Innovation & $0.450^{* *}$ & $0.568^{* *}$ & $0.475^{* *}$ & $0.514^{* *}$ & 1 \\
\hline
\end{tabular}

As a result of the correlation analysis, it was determined that there are positive and significant relationships between the leader effectiveness and learning orientation and the variables of team creativity, effective communication, and service innovation. The positive and significant relationships between the variables also indicates that hypotheses was supported as a result of regression analysis. 
Z. Adiguzel

Table 7. Effects of Independent Variables on Dependent Variables According to Regression Analysis

\begin{tabular}{|c|c|c|c|c|c|}
\hline Independent Variables & Dependent Variables & Standart $\beta$ & Sig. & Adjusted $\mathrm{R}^{2}$ & $\begin{array}{c}\mathbf{F} \\
\text { Value }\end{array}$ \\
\hline Leader Effectiveness & $\begin{array}{c}\text { Effective } \\
\text { Communication }\end{array}$ & $0.436 * * *$ & 0.000 & 0.188 & 82.162 \\
\hline Leader Effectiveness & Team Creativity & $0.348 * * *$ & 0.000 & 0.119 & 48.221 \\
\hline Leader Effectiveness & Service Innovation & $0.433 * * *$ & 0.000 & 0.185 & 80.701 \\
\hline Leader Effectiveness & Learning Orientation & $0.595 * * *$ & 0.000 & 0.352 & 191.996 \\
\hline Learning Orientation & $\begin{array}{c}\text { Effective } \\
\text { Communication }\end{array}$ & $0.711 * * *$ & 0.000 & 0.504 & 356.988 \\
\hline Learning Orientation & Team Creativity & $0.620 * * *$ & 0.000 & 0.383 & 218.917 \\
\hline Learning Orientation & Service Innovation & $0.604 * * *$ & 0.000 & 0.363 & 201.250 \\
\hline
\end{tabular}

\subsection{Supported and Unsupported Hypotheses According to Regression Analysis Results}

Regression analysis was used to test predicted research hypotheses. The supported seven hypotheses, except for the intervening variable effect, are shown in Table 8 according to the results of the regression analysis.

Table 8. Supported or Unsupported Research Hypothesis

\begin{tabular}{|l|c|c|}
\hline Hypotheses & $\begin{array}{c}\text { Supported/ } \\
\text { Unsupported }\end{array}$ & $\begin{array}{c}\text { Level of } \\
\text { Significance } \\
\text { (Sig.) }\end{array}$ \\
\hline $\begin{array}{l}\text { H1: Leader Effectiveness has a positive effect on Learning } \\
\text { Orientation }\end{array}$ & SUPPORTED & $P<0.001$ \\
\hline H2: Leader Effectiveness has a positive effect on Team Creativity & SUPPORTED & $P<0.001$ \\
\hline H3: Learning Orientation has a positive effect on Team Creativity & SUPPORTED & $P<0.001$ \\
\hline $\begin{array}{l}\text { H4: Leader Effectiveness has a positive effect on Service } \\
\text { Innovation }\end{array}$ & SUPPORTED & $P<0.001$ \\
\hline $\begin{array}{l}\text { H5: Learning Orientation has a positive effect on Service } \\
\text { Innovation }\end{array}$ & SUPPORTED & $\mathbf{P}<0.001$ \\
\hline $\begin{array}{l}\text { H6: Leader Effectiveness has a positive effect on Effective } \\
\text { Communication }\end{array}$ & SUPPORTED & $P<0.001$ \\
\hline $\begin{array}{l}\text { H7: Learning Orientation has a positive effect on Effective } \\
\text { Communication }\end{array}$ & SUPPORTED & $\mathbf{P}<0.001$ \\
\hline
\end{tabular}

As a result of the hypothesis tests, which are carried out among the variables of research model, all hypotheses were supported by regression analysis, excluding mediating variables. The regression analysis shows that the relationships between the variables are statistically significant.

Determination of Mediation Variable Effect in Research Model; In research model, the effect of mediation variable of learning orientation on the relationship between independent variable of leader effectiveness and effective communication and on the relationship between team creativity effectiveness and service innovation were examined. As a result, hypotheses was analysed to examine the effects. 
Relationships among Leader Effectiveness, Learning Orientation, Effective Communication, Team Creativity and Service Innovation in the Service Sector

Table 9. Regression Analysis Results of Mediating Variable Effect

\begin{tabular}{|c|c|c|c|c|c|c|}
\hline & $\begin{array}{c}\text { Independent } \\
\text { Variables }\end{array}$ & $\begin{array}{c}\text { Dependent } \\
\text { Variables }\end{array}$ & Standart $\beta$ & Sig. & $\begin{array}{c}\text { Adjusted } \\
\mathbf{R}^{2} \\
\end{array}$ & $\begin{array}{c}\mathbf{F} \\
\text { Value } \\
\end{array}$ \\
\hline \multirow{2}{*}{ Regression } & $\begin{array}{c}\text { Leader } \\
\text { Effectiveness }\end{array}$ & \multirow{2}{*}{$\begin{array}{c}\text { Effective } \\
\text { Communication }\end{array}$} & 0.020 & 0.665 & 0.188 & 82.162 \\
\hline & $\begin{array}{c}\text { Learning } \\
\text { Orientation }\end{array}$ & & 0.699 & 0.000 & 0.502 & 178.173 \\
\hline \multirow{2}{*}{ Regression } & $\begin{array}{c}\text { Leader } \\
\text { Effectiveness }\end{array}$ & \multirow{2}{*}{$\begin{array}{c}\text { Team Creativity } \\
\text { Effectiveness }\end{array}$} & -0.033 & 0.530 & 0.119 & 48.221 \\
\hline & $\begin{array}{c}\text { Learning } \\
\text { Orientation } \\
\end{array}$ & & 0.640 & 0.000 & 0.382 & 109.468 \\
\hline \multirow{2}{*}{ Regression } & $\begin{array}{c}\text { Leader } \\
\text { Effectiveness }\end{array}$ & \multirow{2}{*}{$\begin{array}{c}\text { Service } \\
\text { Innovation }\end{array}$} & 0.113 & 0.032 & 0.185 & 80.701 \\
\hline & $\begin{array}{l}\text { Learning } \\
\text { Orientation }\end{array}$ & & 0.537 & 0.000 & 0.370 & 103.981 \\
\hline
\end{tabular}

It has measured the mediating variable effect of learning orientation in hypotheses, and it was determined that learning orientation has a significant effect on the relationship between independent variables of leader effectiveness and effective communication, as well as having an effect on the relationship between team creativity effectiveness and service innovation. As a result of regression analysis, it was found that it has a significant effect on the hierarchical organization structure between senior managers/leaders and employees.

Measuring the effect of the agent variable by sobel test; In order to explain the interim effect, it is necessary to determine whether the indirect effect of the independent variable (through the mediator) on the dependent variable is meaningful in order to be able to talk about the mediation effect by Baron and Kenny in 1986. Several tests have been developed to accomplish this. One of them is the Sobel test (Sobel, 1982). This test is calculated using uncorrected regression coefficients of the related variables and their standard error values. These criteria are used informally to assess whether mediation is available, but MacKinnon, Warsi, \& Dwyer (1995) popularized statistical-based methods in which mediation can be formally assessed. There are two main versions with the "Sobel test". These; 1944/1947 by Aroian (popularized by Baron \& Kenny as the Sobel test) and by Goodman in 1960.

Table 10. Analysis of the Mediation Variable Effect of Learning Orientation with the Sobel Test in the Relationship Between Leader Effectiveness and Effective Communication

\begin{tabular}{|l|c|c|c|c|c|}
\hline & Input & & Test statistic & Std. Error & p-value \\
\hline a & 0.530 & Sobel test: & 10.16462846 & 0.03483059 & 0 \\
\hline b & 0.557 & Aroian test: & 10.15240067 & 0.03487254 & 0 \\
\hline Sa & 0.038 & Goodman test: & 10.17690054 & 0.03478859 & 0 \\
\hline Sb & 0.045 & & & & \\
\hline
\end{tabular}

If $p$-value is less than $<0.05$, it can explain that there is a mediation effect. 
Z. Adiguzel

Table 11. Analysis of the Mediation Variable Effect of Learning Orientation with The Sobel Test in Relationship Between Leader Effectiveness and Team Creativity Effectiveness

\begin{tabular}{|l|c|c|c|c|c|}
\hline & Input & & Test statistic & Std. Error & p-value \\
\hline a & 0.530 & Sobel test: & 9.25781687 & 0.03188765 & 0 \\
\hline b & 0.668 & Aroian test: & 9.24453405 & 0.03193346 & 0 \\
\hline Sa & 0.038 & Goodman test: & 9.27115712 & 0.03184176 & 0 \\
\hline Sb & 0.045 & & & & \\
\hline
\end{tabular}

If $p$-value is less than $<0.05$, it can explain that there is an mediation effect

Table 12. Analysis of the Mediation Variable Effect of Learning Orientation with the Sobel Test in the Relationship Between Leader Effectiveness and Service Innovation

\begin{tabular}{|l|c|c|c|c|c|}
\hline & Input & & Test statistic & Std. Error & p-value \\
\hline a & 0.530 & Sobel test: & 8.25945388 & 0.03157109 & 0 \\
\hline b & 0.557 & Aroian test: & 8.24570377 & 0.03162374 & 0 \\
\hline Sa & 0.038 & Goodman test: & 8.27327301 & 0.03151836 & 0 \\
\hline Sb & 0.045 & & & & \\
\hline
\end{tabular}

If $p$-value is less than $<0.05$, it can explain that there is a mediation effect. Hypothesis results;

Table 13. Supported or Unsupported Research Hypothesis

\begin{tabular}{|l|c|c|}
\hline Hypotheses & $\begin{array}{c}\text { Supported/ } \\
\text { Unsupported }\end{array}$ & $\begin{array}{c}\text { Level of } \\
\text { Significance (Sig.) }\end{array}$ \\
\hline $\begin{array}{l}\text { H8: Learning Orientation has a mediation variable effect on } \\
\text { the relationship between Leader Effectiveness and Team } \\
\text { Creativity. }\end{array}$ & Supported & $\mathbf{P}<0.001$ \\
\hline $\begin{array}{l}\text { H9: Learning Orientation has a mediation variable effect on } \\
\text { the relationship between Leader effectiveness and Service } \\
\text { Innovation. }\end{array}$ & Supported & $\mathbf{P}<0.001$ \\
\hline $\begin{array}{l}\text { H10: Learning Orientation has a mediation variable effect on } \\
\text { the relationship between Leader Effectiveness and Effective } \\
\text { Communication. }\end{array}$ & Supported & $\mathbf{P}<0.001$ \\
\hline
\end{tabular}

Hypotheses about the effect of mediation variables of learning orientation were tested and it state that learning orientation has a mediating variable effect.

\section{Conclusion and Discussion}

Study was conducted with white collar employees working in private and public organisations in the service sector in the Marmara region, and it was determined that there are significant and positive relationships between leadership effectiveness, learning orientation, and variables of effective communication, team creativity, and service innovation. Training activities that contribute to the development of the employees in the organizations increase the quality of communication between employees and have a positive impact on the creativity activities. Leader effectiveness is accepted as one of the most important elements for positive organisational performance. But, measuring or analyzing the effectiveness of leaders has been a topic of discussion among many researchers in the past who could not come up with a common definition (Arnold et al., 1998) because leader effectiveness shows differences in terms of sectors, culture, and organisational structure. Learning orientation ensures that employees in the organization are able to acquire and share information and knowledge efficiently (Calantone et al., 2002). 
The research shows that it is important to ensure effective communication within the organization in order to avoid unnecessary time loss in formal and informal information sharing, to prevent conflicts and eliminate mistakes while increasing productivity (Massey \& Dawes, 2007). The studies reveal the importance of effective communication and determine that the discussions and brainstorming sessions should be conducted in a healthy manner between employees in order to generate effective team creativity in the organization and to bring individual creativity to the surface. This can be achieved by providing opportunities for employees to share their ideas and thoughts in their departments (Seong \& Choi, 2014). The success of employees in service innovation depends on the provision of a healthy working environment and opportunities because, in this way, the employees can improve themselves in a dynamic structure and participate in creative activities (Chae, 2012).

Leader effectiveness is determined by the understanding and inclusion of the organization of the employees. However, this can only be achieved if leaders and subordinates create strong mutual trust and respect between each other and work as an organization (Epitropaki \& Martin, 2005). If creativity activities generate a high positive impact on the team, the members tend to perceive work environments positively. Such a positive emotional experience motivates team members to interact with each other, share and discuss their ideas and opinions within the team, and create additional alternatives to solve problems (Shalley et al., 2009). At the same time, creative ideas also increase cognitive flexibility, which improves creative abilities, such as accepting different thinking and new perspectives (Isen, 1999). The departments/units of the employees can increase or decrease the chances of a team in generating a creative output. It is suggested that how team members interact with each other and how they work together influences team creativity in a positive or negative direction (Barczak et al., 2010). The essence of service innovation lies in services provided to customers by the businesses. In this respect, customers are becoming an important part of service innovation (Korsching \& El-Ghamrini, 2003). To achieve successful service innovation, the organisations should sustain good coordination in all departments and in a hierarchical structure and the employees should have effective communication between themselves to generate creativity to contribute to the organization, which can be measured by determining customer satisfaction. In a highly competitive environment, the companies enter a race to generate attractiveness and satisfaction by introducing several changes and innovations to meet the needs and requests of their customers (Nemati et al., 2010). Employees in the service sector are more likely to upgrade customer satisfaction with a concept that meets the needs of their customers. Boxer and Rekettye (2011) state that companies should understand customer needs and demands for service since providing service innovation in the most efficient way is based on generating creativity of the employees and providing learning orientation within the organization.

Corporate contributions to research in sectors where competition is intense, as well as to invest in its employees and employees of the institutions themselves should be constant to ensure that development activities establish an active training and development department. Employees knowing that the corporate culture development department of the academy will be established within the organization and will be implemented by experts with in-house training can improve corporate culture, as it should aim to contribute to the development of its employees. In this direction, it is possible to develop creativity activities and communication in the co-operation with employees in the event that learning orientations are improved. At the same time, when taken with sectoral variables and the result of the application of advanced technology and human resources, the results obtained in future studies will bring new insights into what should be done for improving the performance of employees acquisition and will contribute positively to literature.

It is understood that generating a high level of productivity from the workforce is directly proportional with the developments in the organization and senior management's approach towards the employees. More attention needs to be paid to the behaviours and attitudes of the employees and different effects of leadership styles on employees in order to produce better future studies and qualitative research and generate new concepts from the theoretical perspective. It can be possible to obtain new findings and concepts in the field of social sciences, in particular in the field of management and organization, which may arise due to the cultural differences between the regions. It will be possible that future studies can discover new concepts, in terms of theory and analysis, by examining the problems experienced in working life more 
academically and more intensively and contribute to world literature. At the same time, the fact that these comparative analyses are very limited indicates the insufficient theoretical studies in the field of leadership roles in our country. The studies require organisations to be open to research in this field in order to develop themselves. We argue that studies on leadership styles and human resource management approaches to increase employee productivity across sectors and culturally different organizational levels will further contribute to the literature.

\section{References}

Amabile, T. M. (1988). A model of creativity and innovation in organizations. Research in Organizational Behavior, 10(1), 123-167.

Aroian, L. A. (1944/1947). The probability function of the product of two normally distributed variables. Annals of Mathematical Statistics, 18, 265-271.

Arnold, J., Cooper, C., \& Robertson, I. (1998). Work psychology. Understanding human behaviour in the workplace. Harlow, England: Pearson Education.

Aytaç, M., \& Öngen, B. (2012). Doğrulayıcı faktör analizi ile yeni çevresel paradigma ölçeğinin yapı geçerliliğinin incelenmesi. İstatistikçiler Dergisi, 5(1), 14-22.

Barczak, G., Lassk F., \& Mulki, J. (2010). Antecedents of team cCreativity: An examination of team emotional intelligence, team trust and collaborative culture. Creativity and Innovation Management, 19(4), 332-345. doi:10.1111/j.1467-8691.2010.00574.x.

Baron, R. M., \& Kenny, D. A. (1986). The moderator-mediator variable distinction in social psychological research: Conceptual, strategic, and statistical considerations. Journal of Personality and Social Psychology, 51, 1173-1182.

Basadur, M. S. (2004). Leading others to think innovatively together: Creative leadership. Leadership Quarterly, 15, 103121.

Bass, B. M. (1981). Stogdill's handbook of leadership. New York: Free Press.

Bass, B. (1990). Bass \& Stogdill's handbook of leadership: theory research and managerial applications. New York: Free Press.

Boxer, I., \& Rekettye, G. (2011). The relation between perceived service innovation, service value, emotional intelligence, customer commitment and loyalty in B2B. International Journal of Services and Operations Management, 8(2), 222-256.

Brett, J. F., \& VandeWalle, D. (1999). Goal orientation and goal content as predictors of performance in a training program. Journal of Applied Psychology, 84(6), 863-873.

Burns, J. M. (1978). Leadership New York. NY: Harper and Row Publishers.

Button, S., Mathieu, J., \& Zajac, D. (1996). Goal orientation in organizational behaviour research: A conceptual and empirical foundation. Organizational Behaviour and Human Decision Processes, 67, $26-48$.

Büyüköztürk, Ş. (2005). Anket geliştirme. Türk Eğitim Bilimleri Dergisi, 3(2), 133-151.

Calantone, R. J., Cavusgil, S. T., \& Zhao, Y. (2002). Learning orientation, firm innovation capability, and firm performance. Industrial Marketing Management, 31(6), 515-524.

Chae, B. K. (2012). An evolutionary framework for service innovation: Insights of complexity theory for service science. International Journal of Production Economics, 135(2), 813-822. doi:10.1016/j.ijpe.2011.10.015

Cooper, J., Fenimore, J., \& Nirenberg, J. (2012). Leadership effectiveness. Encyclopaedia of leadership. Thousand Oaks, CA: $\quad$ Sage. $\quad$ Retrieved $\quad$ February 11, 2011, from http://www.sagepub.com/northouse6e/study/materials/reference/reference6.4.pdf

Çelik, H. C., \& Bindak., R. (2005). Illköğretim okullarında görev yapan öğretmenlerin bilgisayara yönelik tutumlarının çeşitli değişkenlere göre incelenmesi. Eğitim Fakültesi Dergisi, 6(10), 27-38.

Den Hertog, P. (2000). Knowledge-intensive business services as co-producers of innovation. International Journal of Innovation Management, 4(4), 491-528.

Drazin, R., Glynn, M. A., \& Kazanjian, R.K. (1999). Multilevel theorizing about creativity in organizations: A sense-making perspective. Academy of Management Review, 24, 286-301. 
Relationships among Leader Effectiveness, Learning Orientation, Effective Communication, Team Creativity and Service Innovation in the Service Sector

Epitropaki, O., \& Martin, R. (2005). From ideal to real: A longitudinal study of the role of implicit leadership theories on leader-member exchanges and employee outcomes. Journal of Applied Psychology, 90(4), 659-676. https://doi.org/10.1037/0021-9010.90.4.659

Essén, A. (2009). The emergence of technology-based service systems: A case study of a telehealth project in Sweden. Journal of Service Management, 20(1), 98-121. doi:10.1108/09564230910936878.

Fleenor, J. W., Smither, J. W., Atwater, L. E., Braddy, P. W., \& Sturm, R. E. (2010). Self-other rating agreement in leadership: A review. The Leadership Quarterly, 21(6), 1005-1034.

Gadrey, J., Gallouj, F., \& Weinstein, O. (1995). New modes of innovation: how services benefit industry. International Journal of Service Industry Management, 6(3), 4-16.

Garvin, D. A. (1993). Building a learning organisation. Harvard Business Review, 71(4), 78-91.

Gill, S. J. (2009). Developing a learning culture in nonprofit organizations. Sage.

Goodman, L. A. (1960). On the exact variance of products. Journal of the American Statistical Association, 55, 708-713.

Green, J. M. (2010). Factors affecting perceptions of leadership effectiveness in an international organization: A study of middle management in Finnish MNC. Unpublished PhD dissertation, Aston University, Birmingham, United Kingdom.

Hair, J. F. Robert, P. B., \& David, J. O. (2000). Marketing Research. International Edition, Irwin McGraw-Hill.

Hatane, S. E. (2015). Employee satisfaction and performance as intervening variables of learning organization on financial performance. Procedia-Social and Behavioral Sciences, 211, 619-628.

Hjalager, A., \& Konu, H. (2011). Co-branding and co-creation in wellness tourism: The role of cosmeceuticals. Journal of Hospitality Marketing \& Management, 20(8), 879-901. doi:10.1080/19368623.2011.611727.

Huber, G. P. (1991). Organizational learning: the contributing processes and the literatures. Organization Science, 2(1), 88-115.

Hurley, F. B., \& Hult, G. T. M. (1998). Innovation, market orientation and organizational learning: An integration and empirical examination. Journal of Marketing, 62, 42-54.

İlhan, M., \& Çetin, B. (2014). LISREL ve AMOS programları kullanılarak gerçekleştirilen yapısal eşitlik modeli (YEM) analizlerine ilişkin sonuçların karşılaştırılması. Eğitimde ve Psikolojide Ölçme ve Değerlendirme Dergisi, 5(2), 2642.

Isen, A. M. (1999). Positive affect. Handbook of Cognition and Emotion, 20, 522-539.

Jaw, C., Lo, J., \& Lin, Y. (2010). The determinants of new service development: Service characteristics, market orientation, and actualizing innovation effort. Technovation, 30(4), 265-277.

Jehn, K., \& Mannix, E. (2001). The dynamic nature of conflict: A longitudinal study of intragroup conflict and group performance. Academy of Management Journal, 44(2), 238-251.

Jehn, K. A., \& Bendersky, C. (2003). Intragroup conflict in organizations: A contingency perspective on the conflictoutcome relationship. Research in organizational behavior, 25, 187-242.

Johnson, R. (1980). Elementary statistics (3rd ed.). Belmont: Wadsworth Inc.

Kim, T. T., \& Lee, G. (2013). Hospitality employee knowledge-sharing behaviors in the relationship between goal orientations and service innovative behavior. International Journal of Hospitality Management, 3, 324-337.

Korsching, P. F., \& El-Ghamrini, S. (2003). Rural telephone company adoption of service innovations: A community field theory approach. Rural Sociology, 68(3), 387-409.

Kristensson, P., Matthing, J., \& Johansson, N. (2008). Key strategies for the successful involvement of customers in the co-creation of new technology-based services. International Journal of Service Industry Management, 19(4), 474491. doi:10.1108/09564230810891914

Leenders, R. T., Van Engelen, J., \& Kratzer, J. (2003). Virtuality, communication, and new product team creativity: A social network perspective. Journal of Engineering and Technology Management, 20(1), 69-92.

Limaye, M. R., \& Victor, D. A. (1991). Cross-cultural business communication research: State of the art and hypotheses for the 1990s. Journal of Business Communication, 28, 277- 299.

Linquist, E. F. (1989). İstatistiğe giriş. Çev. H. Tan ve T. Taner. İstanbul: MEB Öğretmen Kitapları Dizisi, 162.

Mackinnon, D. P., Warsi, G., \& Dwyer, J. H. (1995). A simulation study of mediated effect measures. Multivariate Behavioral Research, 30, 41-62. 
Maslyn J. M., \& Uhl-Bien, M. (2001). Leader-member exchange and its dimension: Effects of self-effort and other's effort on relationship quality. Journal of Applied Psychology, 86(4), 697-708.

Massey, G. R., \& Dawes, P. L. (2007). The antecedents and consequence of functional and dysfunctional conflict between marketing managers and sales managers. Industrial Marketing Management, 36(8), 1118-1129.

Mone, M. A., McKinley, W., \& Barker, V.L. (1998). Organizational decline and innovation: A contingency framework. Academy of Management Review, 23(1), 115-132.

Mullen, T. P., \& Lyles, M. A. (1993). Toward improving management development's contribution to organizational learning. Human Resource Planning, 16(2), 35-49.

Nemati, A., Khan, K., \& Iftikhar, M. (2010). Impact of innovation on customer satisfaction and brand loyalty: A study of mobile phones users in Pakistan. European Journal of Social Sciences, 16(2), 299-306.

Nunnally, J. C. (1978). Psychometric theory (2nd ed.). New York: McGraw-Hill.

Oke, A. (2007). Innovation types and innovation management practices in service companies. International Journal of Operations \& Production Management, 27(6), 564-587.

Olkkonen, R., Tikkanen, H., \& Alajoutsijärvi, K. (2000). The role of communication in business relationships and networks. Management Decision, 38(6), 403-409.

Ordanini, A., \& Parasuraman, A. (2011). Service innovation viewed through a service-dominant logic lens: a conceptual framework and empirical analysis. Journal of Service Research, 14(1), 3-23.

Ostroff, C., Atwater, L. E., \& Feinberg, B. J. (2004). Understanding self-other agreement. Personnel Psychology, 57(2), 333-375.

Özdamar, K. (2013). Paket programlar ile istatiksel veri analizi: MINITAB 16-IBM SPSS 21. Nisan Kitabevi.

Pirola-Merlo, A., \& Mann, L. (2004). The relationship between individual creativity and team creativity: Aggregating across people and time. Journal of Organizational Behavior, 25(2), 235-258.

Santos-Vijande, M. L., López-Sánchez, J. A., \& González-Mieres, C. (2012). Organizational learning, innovation, and performance in KIBS. Journal of Management and Organization, 18(6), 870-904.

Sanzo, M. J., Santos, M. L., Vasquez, R., \& Alvarez, L. I. (2003). The effect of market orientation on buyer-seller relationship satisfaction. Industrial Marketing Management, 32(4), 327-345.

Schumacker, R. E. (2006). Conducting specification searches with Amos. Structural Equation Modeling. $A$ Multidisciplinary Journal, 13(1), 118-129.

Senge, P. (1990). The fifth discipline: The art and practice of the learning organization. Random House: London.

Seong, J. Y., \& Choi, J. N. (2014). Effects of group-level fit on group conflict and performance: The initiating role of leader positive affect. Group \& Organization Management, 39, 190-212.

Shah, A., Garg, A., Poddar, B., Aggarwal, N., Mehrotra, P., Goyal, R., \& Tripathi, S. (2010). Indian banking 2020: Making the decade's promise come true. BCG Publication, 1-47.

Shalley, C. E., Gilson, L. L., \& Blum, T. C. (2009). Interactive effects of growth need strength, work context, and job complexity on self-reported creative performance. Academy of Management Journal, 52(3), 489-505.

Sharma, N., Patterson, P. G. (1999). The impact of communication effectiveness and service quality on relationship commitment in consumer, professional services. Journal of services marketing, 13(2), 151-170.

Sinkula, J. M. (1994). Market information processing and organizational learning. Journal of Marketing, 58, 35-45.

Sinkula, J. M., Baker, W. E., \& Noordewier, T. (1997). A framework for market-based organizational learning: Linking values, knowledge, and behavior. Journal of the Academy of Marketing Science, 25(4), 305-318.

Slater, S. F., \& Narver, J. C. (1995). Market orientation and the learning organization. Journal of Marketing, 59(3), 63-75.

Sobel, M. E. (1982). Asymptotic confidence intervals for indirect effects in structural equation models. Sociological methodology, 13, 290-312.

Stogdill, R. M. (1974). Handbook of leadership: A survey of theory and research. New York, US: Free Press.

Sutcliffe, N. G. (1998). The role of leadership in business process reengineering: An empirical study of the relationship between leadership behavior and the reengineering outcome.

Swink, M. (2003). Completing projects on-time: How project acceleration affects new product development. Journal of Engineering and Technology Management, 20(4), 319-344.

Taggar, S. (2002). Individual creativity and group ability to utilize individual creative resources: A multilevel model. The Academy of Management Journal, 45(2), 315-330. 
Tekleab, A. G., Sims, H. P., Jr., Yun, S., Tesluk, P. E., \& Cox, J. (2008). Are we on the same page? Effects of self-awareness of empowering and transformational leadership. Journal of Leadership \& Organizational Studies, 14(3), $185-201$.

Thomas, J. R., Silverman, S., \& Nelson, J. (2015). Research methods in physical activity, 7E. Human kinetics.

Tierney, P., \& Farmer, S. M. (2002). Creative self-efficacy: potential antecedents and relationship to creative performance. Academy of Management Journal, 45, 1137-1148.

Ulijn, J. M., \& Strother, J. B. (1995). Communicating in business and technology: From psycholinguistic theory to international practice.

Yammarino, F. J., \& Atwater, L. E. (1997). Do managers see themselves as others see them? Implications of self-other rating agreement for human resources management. Organizational Dynamics, 25(4), 35-44.

Yefei, Y., Lee, P. K. C., \& Cheng, T. C. E. (2016). Continuous improvement competence, employee creativity, and new service development performance: A front line employee perspective. International Journal of Production Economics, 171, 275-288

Yousafzai, S. Y., Pallister, J. G., \& Foxall, G. R. (2005). Strategies for building and communicating trust in electronic banking: A field experiment. Psychology and Marketing, 22(2), 181-201.

Yukl, G. (2010). Leadership in organizations. (7th ed.). Upper Saddle River, NJ: Pearson Education Inc.

West, M. A. (1990). The social psychology of innovation in groups. In West, M.A. and Farr, J.L. (Eds), Innovation and creativity at work: Psychological and organizational strategies, John Wiley \& Sons, Chichester, 309-333. 